\title{
Comparison of the UKMO and GFDL GCM climate projections in NPP simulations for southern loblolly pine stands
}

\author{
D. A. Sampson ${ }^{1, *}$, E. J. Cooter ${ }^{2, * *}$, P. M. Dougherty ${ }^{3}$, H. Lee Allen ${ }^{1}$ \\ 'Department of Forestry, North Carolina State University, Box 8008, Raleigh, North Carolina 27695, USA \\ ${ }^{2}$ NOAA Air Resources Lab, Research Triangle Park, North Carolina 27711, USA \\ ${ }^{3}$ Westvaco Corporation, Forest Science Laboratory, PO Box 1950, Summerville, South Carolina 29484, USA
}

\begin{abstract}
We used the process model BIOMASS version 13.0 to simulate contemporary net primary production (NPP) and NPP response to climate projections for a doubling of atmospheric $\mathrm{CO}_{2}$ concentration from 2 general circulation models (GCMs) that vary in their $\mathrm{CO}_{2}$ sensitivity: the less sensitive GFDL and the more sensitive UKMO. Increased GCM sensitivity to $\mathrm{CO}_{2}$ is reflected in increased predictions in the magnitude, variation, and range of the climate variables. Simulations used a 40 yr historical climate record, and 2 stand and site conditions to standardize the total NPP response estimates for eighteen $1 \times 1^{\circ}$ grid cells across the southern United States. Contemporary NPP and NPP response estimates from the 18 cells were smoothed using a cell search algorithm to obtain an NPP response index matrix for the entire loblolly pine (Pinus taeda) forest-type. We conducted a sensitivity analysis of the environmental variables projected to change in a $2 \times \mathrm{CO}_{2}$ environment to help interpret simulation output. Contemporary NPP varied from 2.5 to $8.5 \mathrm{Mg} \mathrm{Cha}^{-1} \mathrm{yr}^{-1}$ over the range of loblolly pine. High leaf area index (LAI) simulations had 1.5 to 2 times the productivity of low LAI simulations, but the regional patterns were similar; NPP was correlated with regional differences in precipitation and temperature. The NPP response to future climate and atmospheric changes depended on the GCM used, and on the stand and site condition assumed. Inter-annual estimates for the 18 cell simulations resulted in $a+22$ to $+84 \%$ NPP response for the GFDL climate projections and a -30 to $+94 \%$ NPP response for the UKMO climate projections. The 40 -year average NPP response for the smoothed data ranged from +43 to $+65 \%$ and -1 to $+94 \%$ for the GFDL and the UKMO climate projections, respectively. Consequently, the magnitude and range of the 40 -year average NPP response to the climate projections was directly correlated with the $\mathrm{GCM} \mathrm{CO} 2$ sensitivity. Although increased $\mathrm{CO}_{2}$ sensitivity resulted in broader extremes in the predicted temperature response, precipitation response for the 2 models was similar. The NPP response was also correlated with the patterns in predicted climate change, with regional differences coupled to local climatic conditions. Climate projections from both models produced similar NPP responses when predicted temperatures and precipitation regimes were similar. Elevated ambient $\mathrm{CO}_{2}$ had a greater effect on NPP response than temperature or precipitation in the sensitivity comparisons. Simulations indicate that a $\mathrm{CO}_{2}$ fertilizer effect, assuming no $\mathrm{CO}_{2}$ acclimation, more than compensates for declines in productivity over most of the loblolly pine forest-type associated with projected decreased precipitation and/or projected low to moderate increases in temperature and, therefore, increased maintenance respiration costs.
\end{abstract}

KEY WORDS: Loblolly pine $\cdot$ GCM $\cdot$ UKMO $\cdot$ GFDL $\cdot$ Climate change

\section{INTRODUCTION}

Loblolly pine (Pinus taeda L.) forests represent the major forest type and, economically, the most important timber type in the southern United States. Much of

*E-mail: d_arthur@ncsu.edu

- On assignment to U.S. EPA the commercial success of loblolly pine results from its rapid growth, its hardiness, and its successful adaptation to a wide range in soil types and environmental conditions. On the other hand, its commercial value, as measured by net primary production (NPP), is highly dependent on factors such as soil site characteristics, stand structure, and climate. Uncertainty regarding future climatic conditions raises important questions 
concerning the future viability of this important commercial resource in the southern and southeastern U.S. For instance, assuming an average emission scenario, it has been predicted that atmospheric $\mathrm{CO}_{2}$ concentrations will double near the middle of next century (Houghton et al. 1990). General circulation models (GCMs) predict increases in the global mean temperature of from 1.5 to $4.5^{\circ} \mathrm{C}$ under a doubled $\mathrm{CO}_{2}$ environment (Houghton et al. 1990). Regional analyses from GCM outputs suggest that temperatures may increase by as much as $8^{\circ} \mathrm{C}$ or more, and that precipitation may increase or decrease under a doubling of $\mathrm{CO}_{2}$ for the geographic range currently occupied by the loblolly pine forest-type in the USA (Cooter et al. 1993). Climate-sensitive, and $\mathrm{CO}_{2}$-responsive, process models are needed to assess the potential impacts of elevated $\mathrm{CO}_{2}$ concentrations and the projected climate change on the loblolly pine forest resource.

Large-scale, process-oriented models have been used to assess climate change effects on NPP across broad vegetation types, and across specific regions of the globe (Pastor \& Post 1988, Running \& Nemani 1991). Simulations using TEM (Terrestrial Ecosystem Model) have been conducted for temperate mixed forests that correspond to the loblolly pine forest-type (McGuire et al. 1992, Melillo et al. 1993). However, these simulations were not specific to loblolly pine in their NPP estimates. As such, important physiological controls over production and important driver variables such as leaf area index (LAI) and tissue nitrogen status may not have been adequately characterized. Loblolly pine has only 2 foliage cohorts and, as such, typically exhibits 2 -fold changes in LAI yearly. Standlevel process models that incorporate species-specific physiological controls over NPP may provide information unavailable in more generic, larger-scale models (Malanson 1993).

Experimental studies have thoroughly demonstrated that LAI (Vose \& Allen 1988, Colbert et al. 1990) and soil-plant-atmosphere water relations (Teskey et al. 1987) are the driving variables that determine loblolly pine productivity. Soil site nutrition, and in particular nitrogen, also influences NPP through, principally, controls over LAI (NCSFNC 1991, 1993, Vose \& Allen 1991). Increased LAI increases dry matter production through greater light capture by canopy foliage (Cannell 1989). For any unit LAI, increased water availability or decreased evaporative demand (Teskey et al. 1987 ) and increased ambient $\mathrm{CO}_{2}$ and/or increased foliar nitrogen concentration (Murthy et al. in press) increases photosynthesis and, therefore, productivity. Climate influences both the yearly pattern in foliage biomass accretion (Dougherty et al. 1995) and foliage senescence (Hennessey et al. 1992). Characterization of the magnitude and seasonal pattern in LAI, and site description of stand structure and soil water availability (McNuity et al. 1994), in conjunction with natural climatic variability, will strongly influence NPP in regional simulations. A modified version of the standlevel process model BIOMASS (McMurtrie 1985, McMurtrie et al. 1990) has been developed to incorporate these important driving variables for analyses of simulated NPP for the loblolly pine forest-type.

Our objectives were to develop regional predictions of NPP response to climate change and elevated carbon dioxide concentrations for the loblolly pine foresttype. In this paper we examined contemporary NPP, and compare NPP response simulations from BIOMASS version 13.0 using climate projections from the UKMO and the GFDL GCMs imposed on a 40 yr historical climate record for the Southeast. At present, no data are available at the spatial and temporal scale required for running this model on a site-specific basis at the regional level. We therefore used 2 fixed, contrasting stand and site conditions to standardize the NPP estimates and encompass the potential minimum and maximum NPP response for the loblolly pine forest-type. A sensitivity analysis of the environmental variables predicted to change by the GCMs was conducted to help interpret simulation outputs.

\section{METHODS}

\subsection{Model}

We developed BIOMASS version 13.0 for use in southern loblolly pine stands (Sampson \& Dougherty unpubl.). BIOMASS was originally written for Monterey pine (Pinus radiata D. Don) stands using data from the Biology of Forest Growth experiments conducted in Australia (Benson et al. 1992). We chose to modify BIOMASS because there are strong similarities between Monterey and loblolly pine with respect to physiological controls over photosynthesis and response to nutrient amendments. In addition, they both exhibit similar foliage cohort phenology: LAI usually varies 2 -fold in one growing season due to 2 foliage cohorts. However, some changes to BIOMASS version 12.0 were necessary to adapt it for use in loblolly pine forests. BIOMASS version 12.0 partitions daily net available carbon on a monthly cycle, with the balance of negative and positive carbon days met prior to monthly allocation to component growth (McMurtrie \& Landsberg 1992, McMurtrie \& Wang 1993). This approach bypassed the need for labile carbon storage. Additionally, growth was distributed throughout the 12 mo calendar year based on fixed carbon partitioning coefficients. However, loblolly pine forests have discrete seasonal above-ground growth periods that last 
from 6 to 10 mo depending on the region and the tissue component, with monthly partitioning thought to be too coarse of a resolution for examining loblolly pine carbon budgets. Moreover, preliminary hypotheses suggested that there may be periods where combined growth, construction respiration $\left(R_{c}\right)$, and maintenance respiration $\left(R_{\mathrm{m}}\right)$ costs depend, in part, on stored carbohydrates to meet daily carbon demands. Thus, BIOMASS Version 13.0 was developed.

BIOMASS version 13.0 represents one approach to modeling forest carbon budgets for use in making stand-level estimates of NPP BIOMASS version 13.0 was previously parameterized and validated for a range of loblolly pine stands and sites in the U.S. from Virginia south to Florida and west to Missouri. Our version of BIOMASS uses all of the original process-level equations and algorithms. However, carbon partitioning was changed to a daily time step and, thus, implicit carbon storage that was present in previous versions was changed to incorporate tissue-specific explicit labile carbon storage. A brief description of the changes made to BIOMASS follows.

BIOMASS version 13.0 differs from other models (e.g. Forest-BGC: Bio Geochemical Cycles; TEM: Terrestrial Ecosystem Model) in that it uses empirical estimates of LAI and dynamic, daily-time-step carbon partitioning and labile carbon storage algorithms that balance on a seasonal schedule. The daily budgeting of carbon enabled a more suitable accounting of the seasonal pattern in carbon supply and use. Therefore, a more tightly coupled analyses of biomass accretion and the associated $R_{c}$ and $R_{\mathrm{m}}$ costs on yearly carbon balance of loblolly pine forests could be made. Tissue $R_{\mathrm{m}}$ represents a fundamentally important cost in the daily and seasonal carbon budget of loblolly pine stands (Kinerson 1975, Kinerson et al. 1977). Foliage biomass represents a dominant fraction of the total $R_{\mathrm{m}}$ costs in loblolly pine forests. Because $R_{\mathrm{m}}$ increases exponentially with temperature, and because ambient temperatures are predicted to increase under a doubling of $\mathrm{CO}_{2}$, accurate woody-tissue biomass accretion and accurate representation of the yearly dynamics in LAI are of particular importance to modeling forest production under $2 \times \mathrm{CO}_{2}$ climate.

Daily carbon budgeting in BIOMASS version 13.0 required partitioning net assimilate on a daily time step. Because loblolly pine exhibits discrete, seasonally determined active above-ground growth periods, partitioning may include: (1) labile carbon storage, (2) allocation to above-ground growth, (3) allocation to a 'transparent' below-ground pool, or combinations of all three depending on the source-sink activities. Labile carbon storage follows a fixed hierarchy with foliage $>$ roots $>$ branches $>$ stems based on standing mass for each component. Carbon may be stored or removed from labile pools based on carbon demand rules set by above-ground component phenology and growth rates. Above-ground component growth partitioning is determined by normalized relative growth rate equations that are based on bi-weekly measurements of growth phenology. Carbon partitioning coefficients for each component are estimated from stand age, live crown length, and foliar nitrogen concentrations. These coefficients were developed using empirical data. Tissue-specific growth rates are modified by the carbon partitioning coefficients and normalized on a daily basis.

The below-ground pool acts as a surrogate for fine root production, $R_{\mathrm{c}}, R_{\mathrm{m}}$, and mortality. Information gaps on coarse and fine root production, standing mass, and mortality, especially on a site to site basis, continues to be a common weakness in modeling carbon budgets of forest systems. Transparency in the below-ground pool infers that no active exchange of carbon occurs once allocated to this pool. Simulations indicated that our below-ground pool estimates are comparable, both in magnitude and timing, to needle litter fall which has been used to approximate fine root production when better estimates are lacking (McGuire et al. 1992). In addition, yearly estimates of this fraction are comparable to fine root production estimates found in the literature. Simulations for this study used a constant fine root biomass with initial and ending fine root mass equivalent to initial standing foliage mass. Limited fine root data for slash pine Pinus elliottii (Gholz et al. 1986) and loblolly pine (Mignano 1995) support this assumption.

\subsection{Model assumptions for BIOMASS version 13.0}

(a) All simulations used fixed carbon partitioning ratios. These were determined as the mean response from the empirical data. The relative contribution of NPP to component production in this modal stand was: (1) for foliage, LAI phenology and mass were fixed; (2) for stems, 0.381; (3) for branches, 0.032; (4) for the below-ground transparent pool, 1 - (foliage + stems + branches). During above-ground growth periods the partitioning coefficients summed to equal 1 , and were therefore not absolute ratios of year-end total carbon production for each component.

(b) Foliage, stem, and branch production were modelled using uninterrupted, logistic, asymptotic growth.

(c) Growth phenology of tissue components is not sensitive to changes in $\mathrm{CO}_{2}$ concentrations.

(d) Carbon storage and removal assumed a fixed hierarchy such that: foliage $>$ roots $>$ branches $>$ stems. Maximum carbohydrate storage was assumed for foliage and roots at the start of the growth year. Initial 
labile carbon storage for stem and branch components varied based on tissue nitrogen concentration. The algorithms that determine relative carbohydrate storage for stems and branches were estimated by mass balance during model verification procedures

(e) Maximum labile carbon storage was $13.5 \%$ of the standing mass for foliage and roots, and $6 \%$ of the standing mass for stems and branches.

(f) Carbon used in component production had an associated construction respiration $\left(R_{\mathrm{C}}\right)$ cost whether derived from storage or from current photosynthesis. Construction respiration costs were a constant fraction of available carbon for partitioning regardless of tissue type $\left(R_{c}=0.34\right.$, or $34 \%$ of carbon available for partitioning). This assumption was unchanged from BIOMASS version 12.0 .

(g) Fine root mass remained constant throughout the calendar growth year.

(h) Initial tine root mass and initial standing foliage mass were equivalent.

(i) All carbon allocated to the below-ground pool was reduced by one-half to approximate carbon costs associated with fine root mortality and maintenance respiration. The remaining pool was reduced by the growth respiration constant.

(j) Initial and year ending labile carbon storage pools were equivalent.

(k) The model runs were for a calendar year. Because of the structure of BIOMASS, the model was reset at the start of each growth year so that cumulative growth effects were not examined and, therefore, are not reflected in the model output.

(l) A uniform soil profile composed of a sandy clay loam texture was assumed. Soil profile depth was assumed to be 0.34 and $2 \mathrm{~m}$ for the poor and good water holding capacities, respectively.

(m) The $2 \times$ ambient $\mathrm{CO}_{2}$ concentration used in the simulations varied with the GCM used; the $2 \times$ ambient $\mathrm{CO}_{2}$ values used were 660 and 640 ppm for the GFDL and UKMO models, respectively. Ambient $\mathrm{CO}_{2}$ used in the historical data simulations was assumed to be onehalf the arithmetic mean of these 2 concentrations (325 ppm).

\subsection{Regional climate change analysis}

We developed an NPP response index matrix for the southeastern United States using NPP simulations from historical climate data and climate projections from the 2 GCMs. We define the Southeast as that area which encompasses the 11-state region from Virginia south to northern Florida and west to eastern Oklahoma and Texas. This region does not include Tennessee.

\subsubsection{Geographic considerations}

A sensitivity analysis determined that the NPP projections were more sensitive to assumed stand and site conditions, and to inter-annual variability in climate, than to adjacent cell differences in projected climate (authors' unpubl. data). Therefore, eighteen $1 \times 1^{\circ}$ grid cells were chosen in a systematic matrix across the 102 cells that define the latitudinal and longitudinal extent of the loblolly pine forest-type in the Southeast (Fowells 1965). These $1 \times 1^{\circ}$ cells cover the climatological gradients that exist across the loblolly pine cover-type.

\subsubsection{Climate considerations}

We created a daily climate data base using a subset of the Richman \& Lamb $(1985,1987)$ precipitation data base and a compardble daily maximum and minimum temperature data base developed from procedures similar to those used by Richman \& Lamb $(1985,1987)$ for the period 1949 to 1993. Station locations were selected for completeness of record and their locations relative to the $1 \times 1^{\circ}$ rectangular grid.

Widely available GCM output is usually not suitable for model application on the temporal and spatial scales proposed for our study, and so climate scenarios must be constructed. Such scenarios should offer possible sets of future climate conditions, should be internally consistent and based on good scientific reasoning, but have no specific probability of occurrence.

One approach that has been used in many national and regional assessments was reported by Smith \& Tirpak (1990) and Rosenzweig et al. (1993). It consists of modifying an existing historical time series variable by adding the difference between GCM estimated values for $2 \times \mathrm{CO}_{2}$ and $\mathrm{GCM}$ estimates for present $1 \times \mathrm{CO}_{2}$, or multiplying the original value by the ratio of $2 \times \mathrm{CO}_{2}$ to $1 \times \mathrm{CO}_{2}$. In general, the GCM difference is applied to temperature variables, with the ratio approach then applied to daily precipitation values. The ratio approach as it has been applied to daily precipitation has, in particular, come under repeated criticism as producing physically unjustified scenarios (no change in storm frequency and proportionately larger increases in heavy rain events). Recent studies of regional and national climatic time series suggest that this may, in fact, not be unreasonable given that a similar trend may already be present in the recent climate record (Karl et al. 1995).

The development of climate scenarios used in these analyses is described elsewhere (Cooter et al. in press), and is briefly summarized here. Two models, the GFDL (Geophysical Fluid Dynamics Laboratory of the National Oceanic and Atmospheric Administration, 
Table 1 Comparison of the attributes of the 2 GCMs used in these analyses. Adapted from Cooter et al. (1993)

\begin{tabular}{|c|c|c|}
\hline & GFDL & UKMO \\
\hline $\begin{array}{l}\text { Date of output } \\
\text { generation }\end{array}$ & 1999 (Q-Flux) & 1986 \\
\hline $\begin{array}{l}\text { Numerical solution } \\
\text { technique }\end{array}$ & Spectral (R15) & $\begin{array}{l}\text { Finite } \\
\text { difference }\end{array}$ \\
\hline $\begin{array}{l}\text { Horizontal resolution } \\
\text { (latitude } \times \text { longitude) }\end{array}$ & $4.5 \times 7.5^{\circ}$ & $5.0 \times 7.5^{\circ}$ \\
\hline Vertical resolution. & 9 & 11 \\
\hline Surface characterization & Uniform & Uniform \\
\hline $\begin{array}{l}\text { Convective } \\
\text { parameterization }\end{array}$ & $\begin{array}{l}\text { Moist } \\
\text { adiabatic }\end{array}$ & $\begin{array}{l}\text { Penetrating } \\
\text { convection }\end{array}$ \\
\hline Initial $\mathrm{CO}_{2}$ conc. (ppm) & 300 & 320 \\
\hline
\end{tabular}

NOAA) and the UKMO (United Kingdom Meteorological Office), were used in this study. These models vary slightly in their resolution, parameterization, and $\mathrm{CO}_{2}$ concentration assumed (Table 1). However, they were chosen because they exhibit contrasting sensitivity to $\mathrm{CO}_{2}$. Specifically, the more sensitive UKMO exhibits a greater magnitude and range in the temperature and precipitation responses to $\mathrm{CO}_{2}$ than the less sensitive GFDL GCM. The grid scale of each of these models is different so, to facilitate later analysis, the long-term mean monthly temperature and precipitation differences and ratios discussed previously have been interpolated to a $1 \times 1^{\circ}$ rectangular grid coinciding with the historical Richman-Lamb data base. Our initial scenario, which assumes that equal day- and nighttime warming occurs as estimated by the selected GCMs, was applied to the historical (Richman-Lamb) 40 yr time series of daily maximum and minimum temperature and precipitation data.

We used the 40 yr historical data record to conduct base NPP simulations for each of the eighteen $1 \times 1^{\circ}$ grid cells examined using BIOMASS version 13.0. We then used the corresponding $40 \mathrm{yr}$ future climate projections of the $2 \mathrm{GCMs}$ for a $2 \times \mathrm{CO}_{2}$ climate for each grid cell to simulate future NPP. Daily minimum and maximum temperatures and daily precipitation were the climatic elements required as inputs into the model from these data sets. Important physiological driver variables such as shortwave radiation, vapor pressure deficit, and absolute humidity were estimated in the model using published algorithms present in BIOMASS version 12.0 (McMurtrie \& Landsberg 1992).

For the sensitivity analysis, a 'typical' year of weather observations was selected from the typical climate cell. The typical climate cell was determined by graphical analyses by plotting the 40 yr climate record for temperature and precipitation for the 18 -cell set discussed above to obtain a temperature-precipitation domain for the loblolly pine forest-type. The typical climate cell was chosen as the cell that exhibited a scatter of data corresponding to the center of this domain. This cell corresponds to $32.5^{\circ} \mathrm{N}-88.5^{\circ} \mathrm{W}$, or roughly the center of the southern portion of the natural loblolly pine range. An average climate series could not be used because, while average daily temperatures can be computed, average daily precipitation has little meaning. In addition, the averaging process does not take into account natural patterns of autocorrelation and multi-correlation among temperature and precipitation observations. Such patterns can have important implications for productivity simulations.

The typical climate year was chosen as follows. First, annual temperature means and precipitation totals were computed for each of the 40 years. Only those years that fell within the central one-half of the distribution were retained. Next, the process was repeated for seasonal means of this subset of years. The goal was to select a year whose annual and seasonal means/totals fell within the central portion of the sample distribution. For the observation set representing the $1^{\circ}$ grid cell with centroid located at $32.5^{\circ} \mathrm{N}$ $88.5^{\circ} \mathrm{W}$, the year that best met these criteria was 1964 Thus, the typical year is represented by observations recorded in 1964.

\subsubsection{Stand structure/site considerations}

The development of an index of production response across the Southeast required a standardized stand input data set to enable examination of the main effects of climate and increased $\mathrm{CO}_{2}$ on NPP. We therefore conducted simulations for 2 defined stand structure/site conditions: (1) low LAI and poor water holding capacity (hereafter referred to as 'poor sites'), and (2) high LAI and good water holding capacity conditions (hereafter referred to as 'good sites') (Table 2). These were considered extreme conditions for water holding capacity but representative conditions for high LAI on fertile sites and low LAI on infertile sites. Water holding capacity was estimated using published equations based on soil texture and rooting depth (Saxton et al. 1986). We used a sandy clay-loam texture but varied the rooting profile depth to simulate both poor and good water holding capacity conditions (Table 2). Both stands were similar with respect to branch and stem standing woody biomass, tree height, crown depth, stand density, and component nitrogen concentrations.

Input data used to describe these fixed stand and soil site conditions were obtained from empirical data from a study that previously examined the response of 
Table 2. Stand parameters and soil site characteristics of the 2 fixed stand and site conditions used in the simulations of contemporary net primary production (NPP) and NPP response to the climate projections from the 2 GCMs used in these analyses

\begin{tabular}{|c|c|c|}
\hline Parameter & $\begin{array}{l}\text { Low LAI/ poor } \\
\text { water holding } \\
\text { capacity }\end{array}$ & $\begin{array}{c}\text { High LAI / good } \\
\text { water holding } \\
\text { capacity }\end{array}$ \\
\hline \multicolumn{3}{|c|}{ Initial standing mass ( $\mathrm{Mg}$ biomass $\mathrm{ha}^{-1}$ ) } \\
\hline Foliage & 1.65 & 3.72 \\
\hline Stems & 56.3 & 56.3 \\
\hline Branches & 9.03 & 9.03 \\
\hline Roots & 1.65 & 3.72 \\
\hline \multicolumn{3}{|l|}{$\operatorname{LAI}\left(\mathrm{m}^{2} \mathrm{~m}^{-2}\right)$} \\
\hline Minimum & 0.78 & 1.60 \\
\hline Maximum & 1.58 & 3.15 \\
\hline Foliar $\mathrm{N}$ concentration $(\%)$ & 1.08 & 1.54 \\
\hline Average tree height (m) & 12.3 & 12.3 \\
\hline Soll protile depth (m) & 0.3 & 2.0 \\
\hline $\begin{array}{l}\text { Available water storage } \\
\text { in rooting profile }(\mathrm{mm})\end{array}$ & 56 & 374 \\
\hline
\end{tabular}

mid-rotation loblolly pine stands to fertilization (NCSFNC 1993). We used a 30-stand subset of this region-wide study that represents a range of stands and sites from across the southeastern United States (Table 3). Stand parameters (i.e. standing mass in stems and branches, stand density, component nitrogen concentrations, and crown characteristics) used a modal stand from this data set. BIOMASS permits using empirical estimates of LAI directly in the model. We therefore used monthly estimates for low and high LAI input files from 2 stands in the data set that represent, respectively, the lowest and highest LAI and phenology found. These LAI estimates were previously derived from needle litterfall techniques (Vose \& Allen 1988).

The fixed stand and site conditions provided an estimate of a potential minimum and maximum response for loblolly pine attainable based on the stand parameters used. We were therefore able to generate productivity projections even though we lacked cell-specific stand and site data for all required input variables. This approach permits an evaluation of the direct effects of climate and $\mathrm{CO}_{2}$ concentration on NPP and NPP response rather than confounding the results with the effects that stand structure and soil site conditions have on NPP simulations (authors' unpubl. data). BIOMASS simulations run for 1 calendar year. As such, stand and site parameters are re-set to initial conditions prior to the start of each year of simulation for multiple year runs. Although this limitation of BIOMASS means it cannot address questions pertaining to
Table 3. Stand parameters and site characteristics of the 30 loblolly pine stands used to establish the modal stand used in the sensituvity analyses. These stands represent a range of intermediate-age loblolly pine stands from across the Southeast

\begin{tabular}{|c|c|}
\hline Attribute & Mean and (range) \\
\hline \multicolumn{2}{|c|}{$\begin{array}{l}\text { Initial standing mass ( } \mathrm{Mg} \text { biomass } \\
\left.\mathrm{ha}^{-1}\right) \text { in: }\end{array}$} \\
\hline Foliage and fine roots & $2.70(1.92-3.72)$ \\
\hline Stems & $54.5(32.1-90.9)$ \\
\hline Branches & $8.9(6.3-14.0)$ \\
\hline Stand density (trees ha-1) & $1387(864-1870)$ \\
\hline Average tree diameter $(\mathrm{cm})$ & $15.4(12.4-20.0)$ \\
\hline Peak LAI $\left(\mathrm{m}^{2} \mathrm{~m}^{-2}\right)$ & $2.4(1.8-3.15)$ \\
\hline Canopy height (m) & $12.2(9.2-17.0)$ \\
\hline Age $(y r)$ & $14.8(11-18)$ \\
\hline $\begin{array}{l}\text { Available soil watcr in } \\
\text { first rooting profile (mm) }\end{array}$ & $53.1(35.1-76.4)$ \\
\hline $\begin{array}{l}\text { Available soil water in } \\
\text { total profile (mm) }\end{array}$ & $177(117-203)$ \\
\hline Foliar nitrogen $(\%)^{\mathrm{a}}$ & $1.18(1.04-1.91)$ \\
\hline \multicolumn{2}{|c|}{$\begin{array}{l}\text { "Foliar nitrogen concentration represents the median } \\
\text { value for the } 30 \text { stand data set }\end{array}$} \\
\hline
\end{tabular}

a developing stand, it does permit direct evaluation of climatic effects on NPP in relation to stand conditions.

Several assumptions were necessitated by this approach. Specifically, it was assumed that both stand and site conditions exist, or could exist, for each cell examined. Nitrogen availability and uptake predominantly determines the maximum LAI obtainable in most loblolly stands (NCSFNC 1991). The occurrence and relative distribution of low and high LAI stands in any cell would largely depend on $\mathrm{N}$ availability, the soil water relations, and forest management practices foperational fertilization, thinning, etc.) specific to each cell. Additionally, the occurrence of good and poor water holding capacity situations may or may not be found in each cell.

\subsubsection{BIOMASS version 13.0 simulations and outputs}

Model sensitivity to ambient and $2 \times$ ambient $\mathrm{CO}_{2}$ concentration required the use of the Farquhar et al. (1980) biochemical photosynthesis model found in BIOMASS (McMurtrie et al. 1992). We assumed that the nitrogen effects incorporated into these series of algorithms were suitable for loblolly pine simulations.

Annual NPP was simulated for each of the 18 grid cells for the 40 yr historical record and the 2 GCM- 
modified $40 \mathrm{yr}$ future climate projections. The annual predictions were used to calculate contemporary and future average annual NPP for each of the 18 cells as:

$$
\text { NPP Aemporary or future }=\frac{\sum \text { Annual NPP }}{40}
$$

and the NPP response to climate conditions projected under a doubling of $\mathrm{CO}_{2}$ for each of the 18 cells as:

$$
\text { Average NPP response }=\frac{\sum \frac{N P P_{\text {tuture }}-N P P_{\text {contemporary }}}{N P P_{\text {contemporary }}}}{40} \times 100
$$

The 40-year average NPP and NPP response data from the 18 grids were smoothed across the 102 grid cells found in the loblolly pine forest-type using a cellsearch algorithm (Anonymous 1995). This enabled a region-wide presentation of the NPP and NPP response simulations. As previously mentioned, simulations for all 102 grid cells was not feasible, nor justified given the lack of sensitivity in adjacent cell climate in the NPP predictions. These NPP response data for the 40 -year GCM climate projections are considered to be an index of change rather than an absolute change from current conditions. The NPP response estimates represent response to an instantaneous doubling of ambient $\mathrm{CO}_{2}$.

\subsection{Sensitivity analysis of environmental variables}

Interpretation of the simulation output was aided by conducting a sensitivity analysis of the driving environmental variables predicted to change in a $2 \times \mathrm{CO}_{2}$ environment. The 3 primary environmental variables examined here were $\mathrm{CO}_{2}$ concentration, temperature, and precipitation. Important effects such as cloud cover and the accompanying changes in solar radiation were reflected in the temperature data.

Stand and site condition were held constant while we modified $\mathrm{CO}_{2}$ concentration, temperature, and precipitation separately. We used ambient $\mathrm{CO}_{2}$ (350 ppm), $1.5 \times$ ambient, and $2 \times$ ambient $\mathrm{CO}_{2}$ concentrations and the typical climate year, for the typical climate cell, to simulate NPP using the 2 defined stand conditions. We then increased daily minimum and maximum temperatures by 3 and $6^{\circ} \mathrm{C}$ to examine the sensitivity of the model to temperature. Finally, for those days that had precipitation events in the typical climate year, we increased and decreased daily precipitation by 25 and $75 \%$ of 1 standard deviation of the 40 yr mean daily precipitation to examine the sensitivity of the model to precipitation. The influence of decreased temperature on NPP was not addressed; none of the GCM climate projections suggested decreased temperatures in a $2 \times \mathrm{CO}_{2}$ environment. However, simulations using decreased ambient air temperatures in this model would result in decreased $R_{\mathrm{m}}$ and, therefore, increased NPP, with the magnitude of the increase depending on the magnitude of the temperature decrease.

\section{RESULTS}

\subsection{Contemporary NPP and climate}

Contemporary NPP ranged from 2.6 to over $8.0 \mathrm{Mg} \mathrm{C}$ $\mathrm{ha}^{-1} \mathrm{yr}^{-1}$ across all regions for both stand and site conditions. These estimates were consistent with published literature (Table 4). The good site conditions resulted in 1.5 to 2 times the productivity of poor site conditions (Fig. 1a, b). Although the magnitude in the NPP estimates varied, both stand and site conditions had similar regional patterns in productivity. These regional patterns are strictly climate-driven in this analysis. As such, for stands of similar attributes as examined here, regions along the east coast of North and South Carolina have the greatest climate-induced NPP potential while eastern Texas and Oklahoma exhibit the lowest.

Contemporary, 40-year-average mean daily growing season precipitation and temperature varied tremendously across the loblolly pine forest-type. Precipitation varied 2 -fold, ranging from 2.5 to $5 \mathrm{~mm}$ rainfall $\mathrm{d}^{-1}$ (Fig. 1C). Mean daily growing season temperature increased by $50 \%$ from Virginia to northern Florida, ranging from roughly 16.5 to $24.5^{\circ} \mathrm{C}$ (Fig. 1d). Precipi-

Table 4. Comparison of net primary productivity (NPP) simulated in this study with published literature

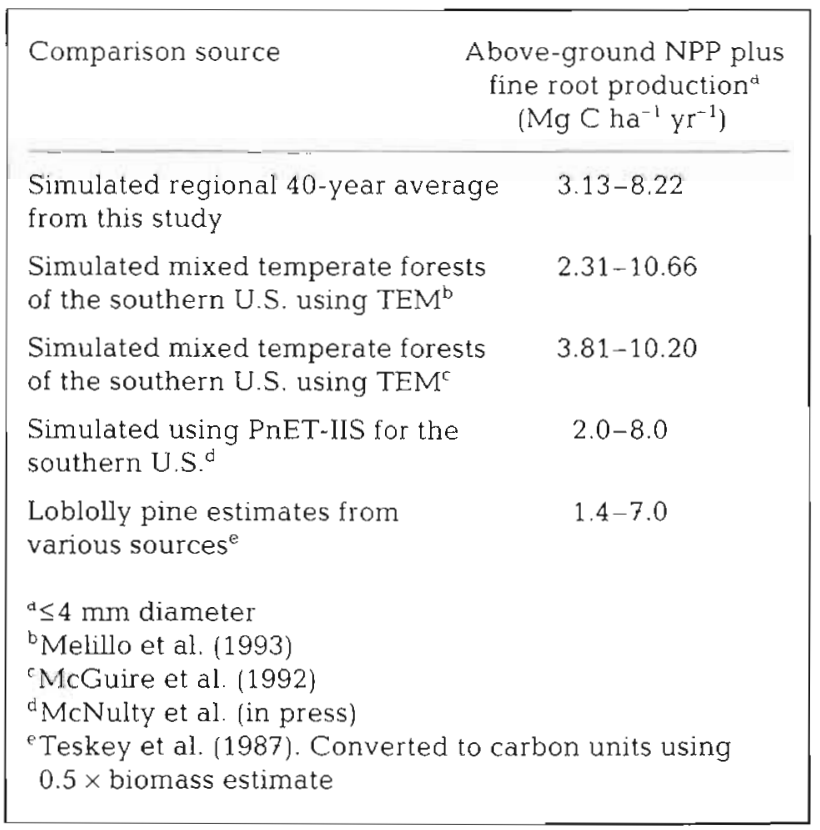



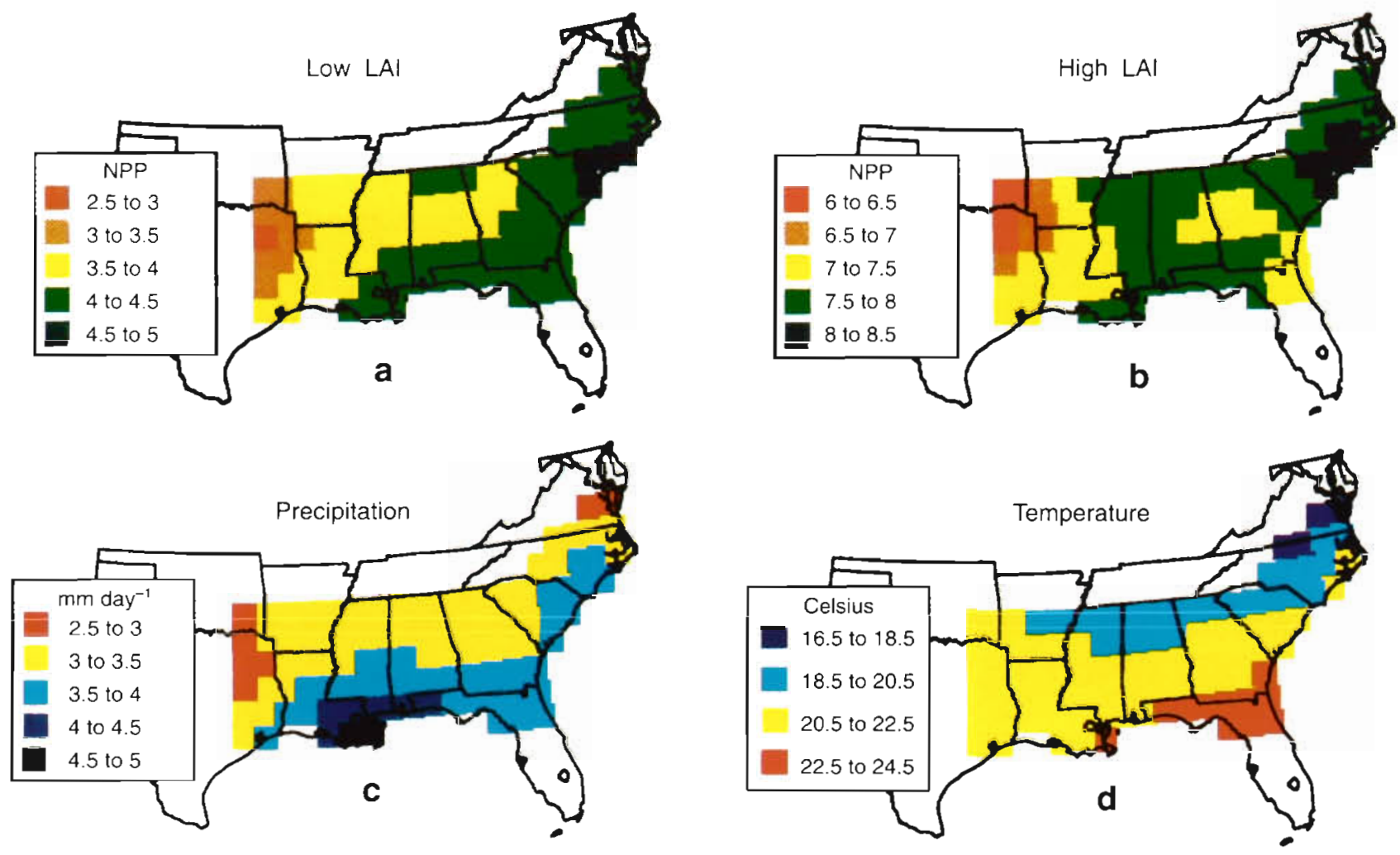

Fig. 1. Contemporary net primary production (NPP, $\mathrm{Mg} \mathrm{Cha} \mathrm{C}^{-1} \mathrm{y}$ ) and climate for the loblolly pine forest-type of the southeastern United States. Simulations represent the 40-year average NPP for the Southeast for: (a) low LAI and poor water holding capacity simulations, and (b) high LAI and good water holding capacity simulations. Included is output for the 40-year-average mean daily growing season: (c) precipitation, and (d) temperature

tation and temperature both generally increased with decreasing latitude. One exception was southeastern Oklahoma and northeastern Texas, where precipitation was similar to east-central Virginia (i.e. 2.3 to $3 \mathrm{~mm} \mathrm{~d}^{-1}$ ) (Fig. 1c).

The regional patterns in simulated contemporary NPP were coupled to the local temperature and precipitation regimes. For example, moderately high to high productivity regions corresponded to moderate to high precipitation and moderate to low temperature regimes, especially for low LAI simulations (Fig. 1c, d). The low productivity areas for both low and high LAI conditions were associated with very low growing season precipitation in conjunction with moderately high growing season temperatures.

The response surface for simulated contemporary NPP as influenced by temperature and precipitation for the good site conditions illustrates the regional effect of local, yearly variation in climate on NPP (Fig. 2). Mean daily growing season precipitation had Iittle effect on simulated NPP for very low mean daily growing season temperatures (Fig. 2). Likewise, during high precipitation years, mean daily growing season temperature had little effect on NPP. However, the

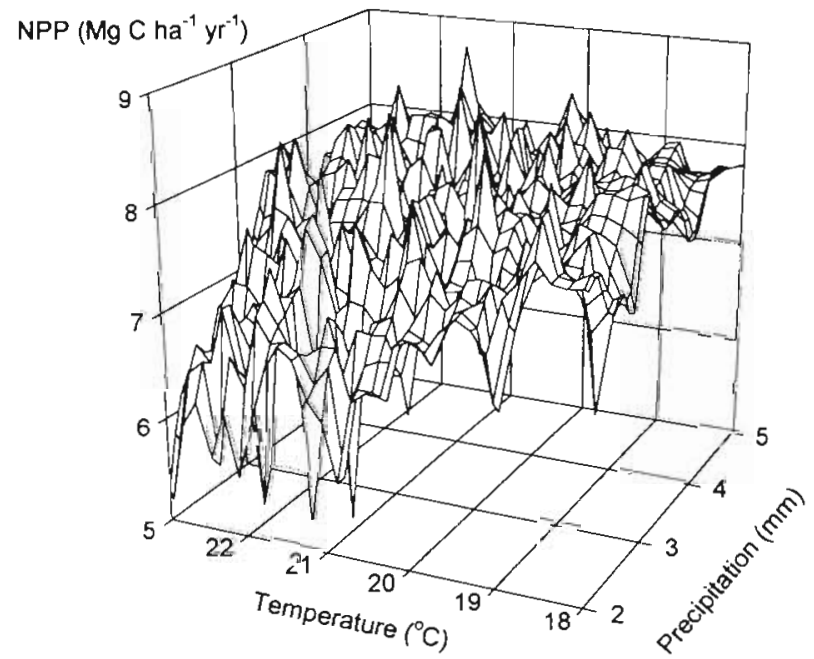

Fig. 2. The response surface for the effect of mean daily growing season temperature and precipitation on simulated net primary productivity (NPP) for high LAI/good soil water holding capacity simulations. Regional effects of climate (climatic extremes, temporal patterns, and solar radiation) are reflected in variation in NPP observed for any temperature and precipitation combination 


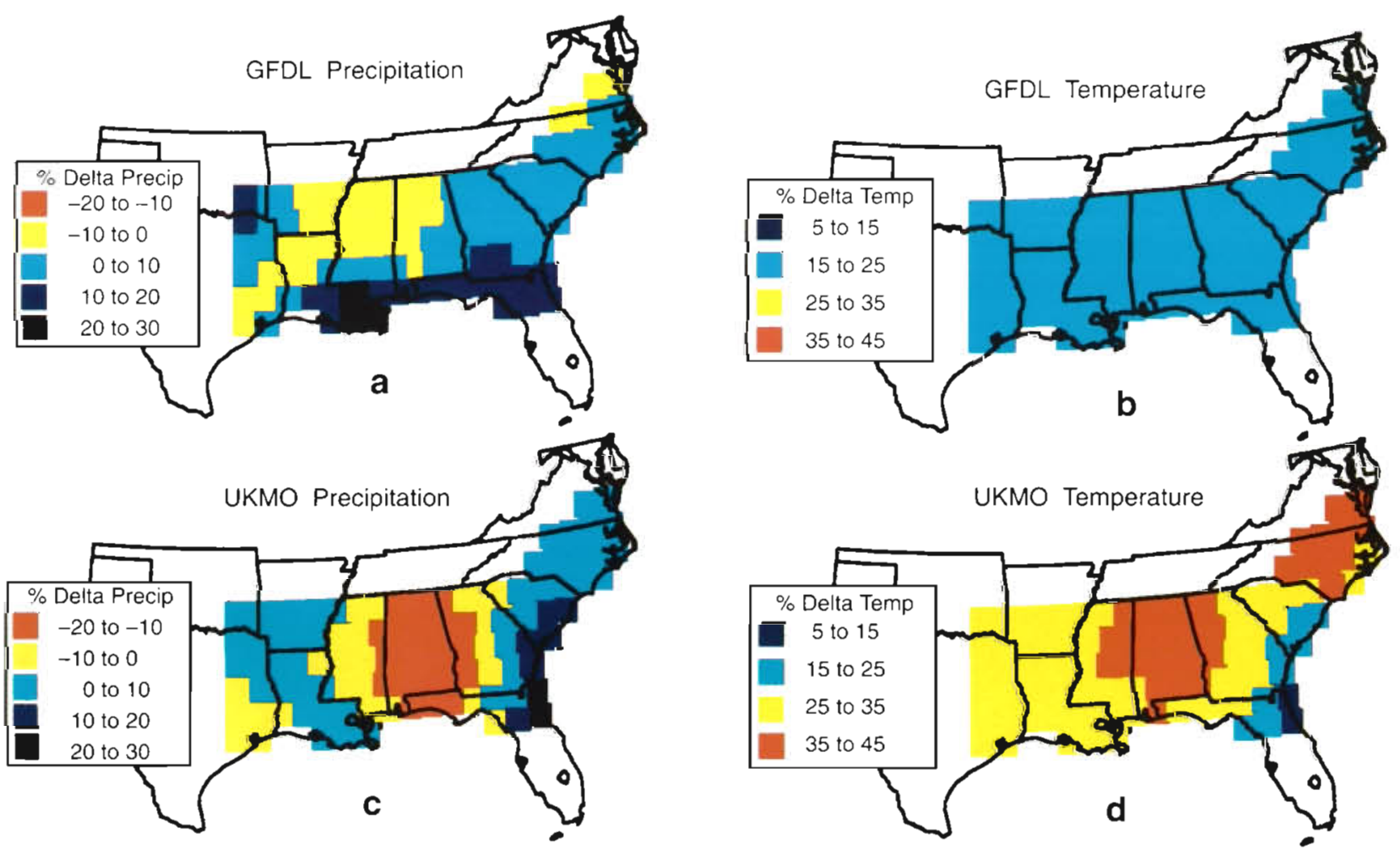

Fig. 3. The proportional change in mean daily growing season temperature and precipitation for the 2 GCMs. (a) GFDL precipitation, (b) GFDL temperature, (c) UKMO precipitation, and (d) UKMO temperature projections

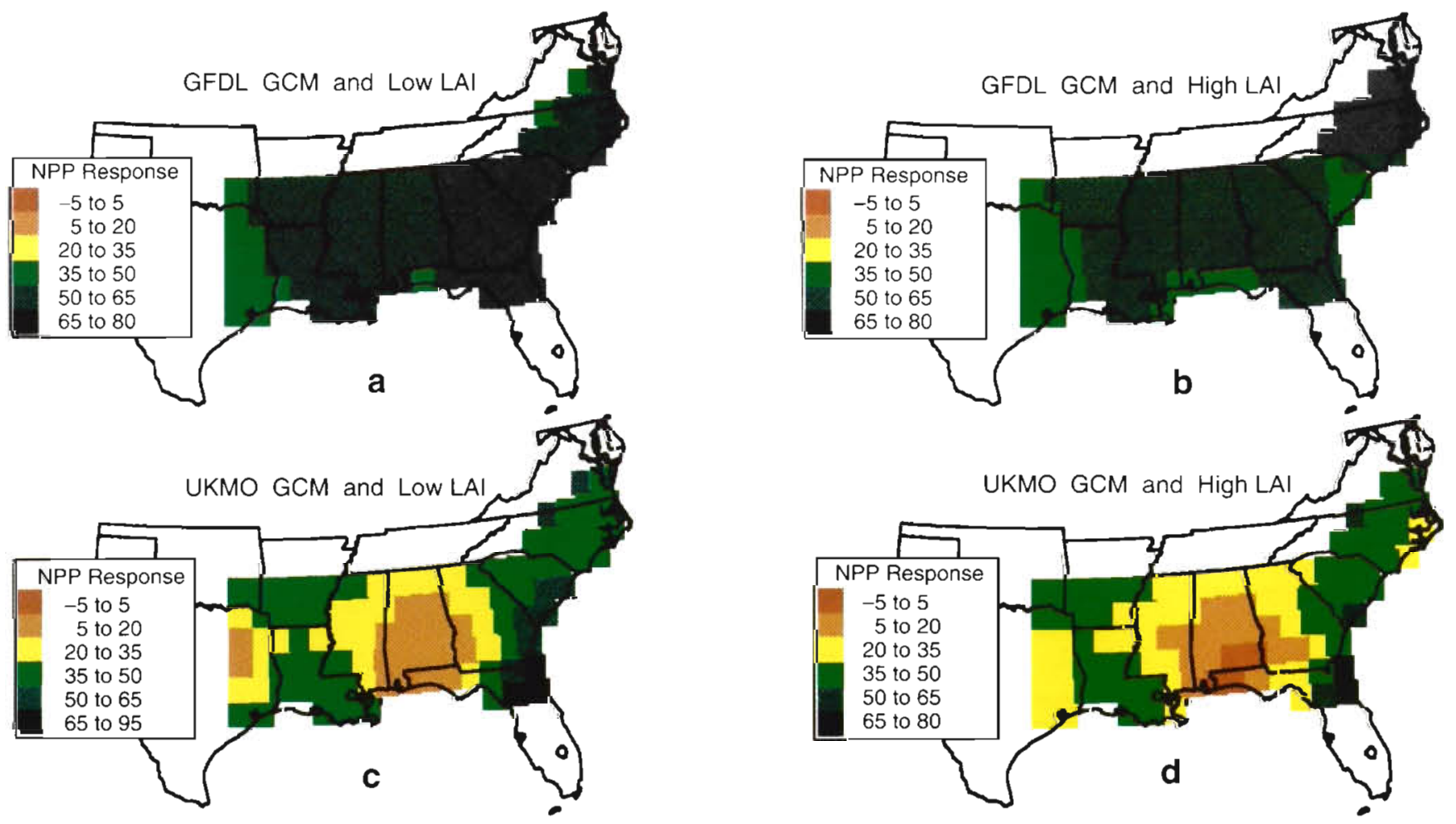

Fig. 4. Simulated net primary production (NPP) response to the climate projections for the 2 GCMs and 2 stand and soil site conditions. Simulations are for the: (a) GFDL GCM climate with low LAI and poor water holding capacity, (b) GFDL GCM climate with high LAI and good water holding capacity, (c) UKMO GCM climate with low LAI and poor water holding capacity, and (d) UKMO GCM climate with high LAI and good water holding capacity 
effect becomes precipitously more pronounced as precipitation declines (Fig. 2). A similar surface, but lower absolute response with a diminished temperature effect, was observed for the poor site simulations. High variability in any temperature-precipitation combination reflects regional influences on NPP that include, in part, radiation load and temporal patterns in precipitation and cloud cover.

\subsection{NPP response to climate projections}

Mean daily growing season precipitation and temperature projections varied between the 2 GCMs, with the magnitude and range similar for precipitation but markedly different for the temperature projections (Fig. 3a-d). The GFDL precipitation ranged from a $10 \%$ decrease to a $30 \%$ increase in mean daily rainfall (Fig. 3a). Coastai areas were projected to have an increase, with Central Interior regions of the loblolly pine forest-type corresponding to northwestern Georgia, northern Alabama, and southeastern Missouri predicted to decrease. Northwestern areas (southeastern Oklahoma and northeastern Texas) were also projected to increase in precipitation, with a $20 \%$ rise in rainfall expected (Fig. 3a). Projected temperatures for the GFDL projections indicate a uniform, moderately high increase of 15 to $25 \%$ for the entire loblolly pine forest-type (Fig. 3b).

In striking contrast, the UKMO climate in a $2 \times \mathrm{CO}_{2}$ environment varies tremendously, with strong regional differences in both the precipitation and temperature regimes observed. Mean daily growing season precipitation is projected to vary from -20 to $+30 \%$. The greatest change in precipitation is projected for coastal South Carolina, Georgia, and the Atlantic Seaboard of Florida (Fig. 3c). In general, southern Missouri, southeastern Oklahoma, northeastern Texas, and most of Louisiana are projected to have moderate precipitation increases. Of particular interest, western Georgia, Alabama, eastern Mississippi, and the western Florida panhandle are predicted to exhibit up to a $20 \%$ reduction in precipitation as projected by the UKMO GCM (Fig. 3c). Regional patterns in mean daily growing season temperatures are much more dynamic in the UKMO GCM than the GFDL climate projections. Temperatures are expected to increase from 5 to $45 \%$ in a $2 \times \mathrm{CO}_{2}$ climate (Fig. 3d). Virginia and North Carolina, and most of Alabama are expected to warm the most, with Atlantic coastal areas of South Carolina, Georgia, and Florida warming the least.

The comparison of NPP production response for the 2 GCM climate projections indicates drastically divergent predictions-both in magnitude and range-for the GFDL and UKMO models. Overall, simulations suggest increased productivity in a $2 \times \mathrm{CO}_{2}$ environment throughout most of the loblolly pine forest-type for both GCMs (Fig. 4a-d). Simulations using the GFDL climate for poor site conditions suggest a 40 to $60 \%$ increase in loblolly pine productivity (Fig. 4a). Slightly higher production response was indicated for Florida when compared to the rest of the loblolly pine range. The good site simulations had a very similar production response to that observed in the low LAI simulations (Fig. 4b). In addition, there was no regional stratification in the NPP response predictions for the range in response portrayed, with a 40 to $60 \%$ increase in NPP predicted for the entire range of loblolly pine for both stand and site conditions using the GFDL climate projections.

The UKMO NPP simulations, in contrast, had a much greater range in the expected proportional change in NPP, with negative responses observed. Poor site simulations suggested a 5 to $95 \%$ response, with strong regional differences predicted. Atlantic coastal areas had, in general, the greatest NPP response with Alabama, eastern Mississippi, western Georgia, and eastern Texas exhibiting the lowest NPP response (Fig. 4c). Net primary production response for good site conditions exhibited a similar regional pattern to the poor site simulations, however the magnitude of response was slightly reduced with a negative response observed for Gulf areas corresponding to the western Florida panhandle and to south-central Alabama (Fig. 4d).

As observed with the contemporary climate data, the NPP response observed for the 2 GCMs was correlated with the climate scenarios predicted. The increased NPP predicted using the GFDL climate corresponded to generally increased precipitation and uniformly increased temperatures. The strong regional separation in the NPP response for the UKMO climate corresponded to the precipitation-temperature interaction, with the lowest production response associated with lower precipitation and higher temperatures and the highest production response found for the inverse (Fig. 3c, d \& 4c, d). Areas of similar precipitation and temperature projections from the 2 GCMs had a similar NPP response (e.g. Atlantic coastal regions).

\subsection{Sensitivity analyses}

Elevated ambient $\mathrm{CO}_{2}$ had a greater effect on NPP response than temperature or precipitation in the sensitivity comparisons. Poor site and good site simulations had generally a similar response to increased $\mathrm{CO}_{2}$ and temperature. Specifically, NPP increased by roughly 45 and $75 \%$ for 1.5 and $2 \times$ ambient $\mathrm{CO}_{2}$ respectively, for both stand and water-holding-capac- 
ity conditions (Fig. 5a). The slightly higher production response observed for low LAI simulations is attributed to overall reduced maintenance respiration costs of the lower-foliage-mass stands. Increasing temperatures by 3 and $6^{\circ} \mathrm{C}$ decreased NPP by approximately 20 and $45 \%$, respectively, for both stand and site conditions. However, the 2 stand/site conditions diverged in their response to addition or subtraction of precipitation. Increasing daily precipitation in those days that it rained in the typical climate year by 0.25 and $0.75 \times 1$ standard deviation of the daily 40 yr mean had little effect on NPP in low or high LAI simulations (Fig. 5b). In addition, decreasing precipitation for the good site simulations had no effect on NPP response. However, NPP decreased by roughly 2.5 and $15 \%$ for poor site simulations when daily precipitation was decreased by 0.25 and $0.75 \times 1$ standard deviation of the 40 yr daily mean (Fig. 5b).

These single-factor effects are additive for multiple-factor influences on NPP. For example, the $75 \%$ increase in NPP with a doubling of atmospheric $\mathrm{CO}_{2}$ is reduced to a net $60 \%$ gain for a $+3^{\circ} \mathrm{C}$ increase in temperatures and no change in precipitation. These are integrated in the model to obtain an overall effect based on the current or projected climate and the assumed $\mathrm{CO}_{2}$ concentration. a
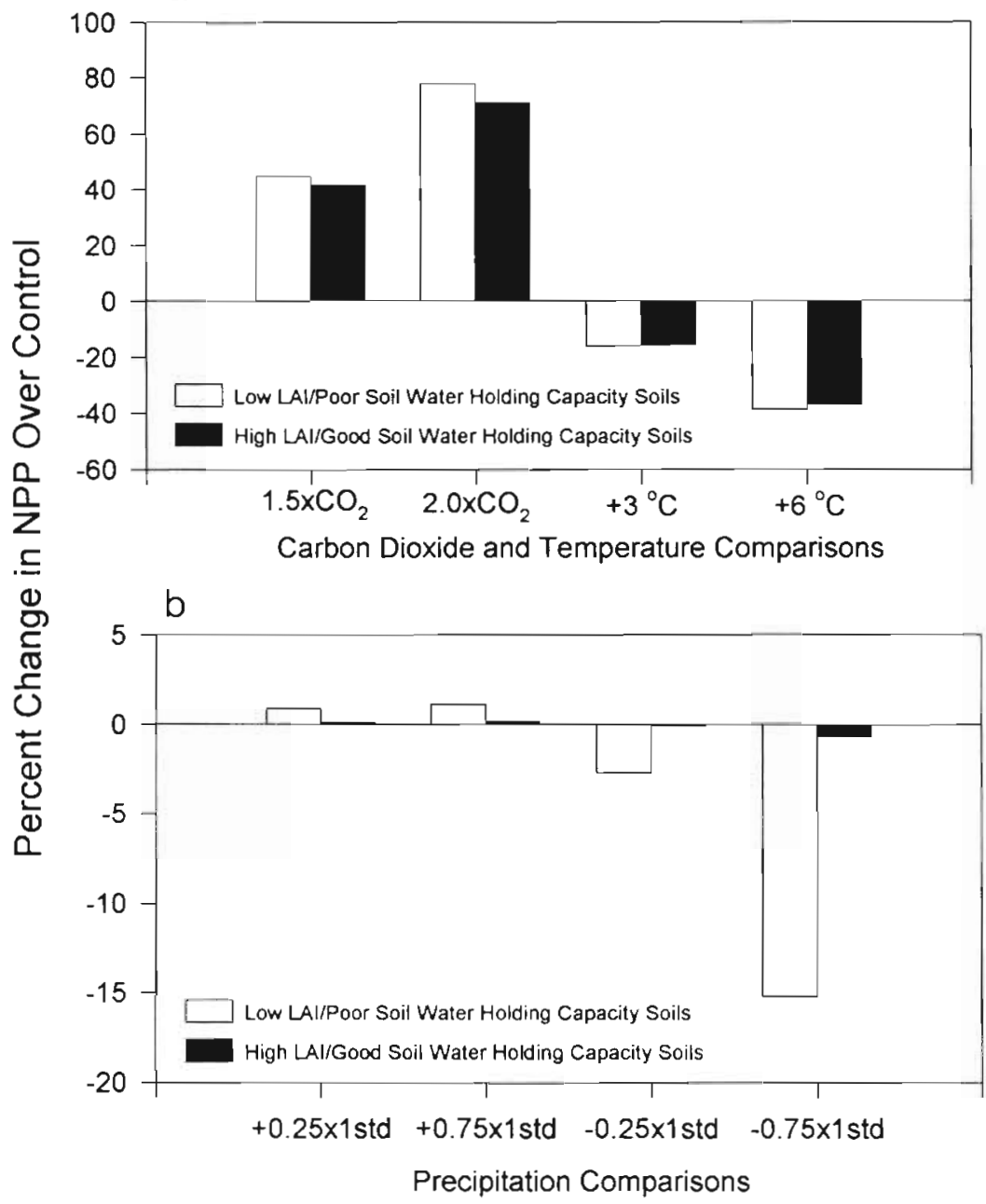

Fig. 5. Sensitivity analysis of the effect of 2 levels of (a) ambient carbon dioxide concentration and increased temperature and (b) altered precipitation on net primary production response ([(altered - base)/base $) \times 100)$ for the process model BIOMASS version 13.0. Simulation data represent the 40-year average response using contemporary climate data from a west-central Alabama, eastcentral Mississippi cell; 1 std $=1$ standard deviation of the 40 -year mean

\section{DISCUSSION}

Results presented here demonstrate that simple combinations of LAI, water holding capacity, and carbon dioxide concentration result in multiple, regional interactions for simulations of contemporary NPP and NPP response to the climate projected for a $2 \times \mathrm{CO}_{2}$ environment. Simulations suggest generally increased productivity with a doubling of atmospheric $\mathrm{CO}_{2}$. This results from a $\mathrm{CO}_{2}$ fertilization effect, where projected increases in atmospheric $\mathrm{CO}_{2}$ compensate for projected increases in temperatures, or decreases in precipitation, throughout most of the loblolly pine foresttype (Fig. 5, and see Figs. $1 \& 3$ ). The magnitude of the increase, or the occurrence of a decreased response, will be influenced by the LAI and water holding capac- ity, and determined by the temperature and precipitation scenario used as predicted by the GCM.

No direct comparison of NPP from other process model predictions for loblolly pine could be made. However, TEM has been used (McGuire et al. 1992, Melillo et al. 1993) to simulate NPP for temperate mixed forests in the southern USA that correspond regionally to the loblolly pine forest-type. If we assume that these estimates adequately represent loblolly pine productivity, our estimates of contemporary NPP were generally very comparable with simulations from TEM for Melillo et al. (1993) (2.31 to $10.66 \mathrm{Mg} \mathrm{C} \mathrm{ha}^{-1} \mathrm{yr}^{-1}$ ) and for McGuire et al. (1992) (3.81 to $10.20 \mathrm{Mg} \mathrm{C} \mathrm{ha}^{-1}$ $\mathrm{yr}^{-1}$ ). This finding demonstrates that our fixed stand and site conditions may have encompassed the natural range in loblolly pine productivity. Because of the scal- 
ing differences between those studies and ours, no meaningful regional comparisons could be made.

Results presented here suggest that production potential may be set by the LAI, moderated by the water holding capacity, but driven by the local climate. Simulations from TEM for South American Temperate Forests indicate a strong correlation (0.93) between NPP and temperature, but not precipitation (not significant) (Raich et al. 1991). Averaging the $2 \mathrm{LAI} /$ waterholding-capacity conditions, we found significant, but lower, correlations for temperature $(\mathrm{p}<0.0001, \mathrm{n}=711$ $\mathrm{r}=-0.25)$ and precipitation $(\mathrm{p}<0.0001, \mathrm{n}=711, \mathrm{r}=$ 0.43 ).

As with the contemporary NPP estimates, no direct comparisons of NPP response to an 'instantaneous' doubling of $\mathrm{CO}_{2}$ for loblolly pine could be made. However, a comparison of NPP response for temperate mixed forests using TEM in GFDL climate projections was possible. Our estimates of NPP response (40 to $65 \%$ were somewhat similar, although generally higher and less variable than those predicted by TEM (Melillo et al. 1993) ( -5 to $+50 \%$ ). No direct evaluation of the differences observed here can be performed. However, the 2 models do differ in their structure and time step (see Raich et al. 1991, McMurtrie \& Landsberg 1992). Notwithstanding, the similarity in the NPP estimates for the contemporary climate suggests: (1) the climate scenarios used may differ, or (2) the processes affecting NPP associated with a $2 \times \mathrm{CO}_{2}$ environment may differ between the 2 models. We used a $1 \times 1^{\circ}$ rectangular grid while Melillo et al. (1993) used a $0.5 \times 0.5^{\circ} \mathrm{grid}$. Interpolation of climate variables from the GCM grid to the grid scale used in the NPP simulations will influence the climate projections (Ghan 1992). No spatial comparison of regional differences in NPP response for loblolly pine examined here and NPP response for the temperate mixed forests examined by Melillo et al. (1993) could be made.

Regional differences in the NPP response to a $2 \times \mathrm{CO}_{2}$ climate in this study are largely explained by the relative and absolute difference, and combination of differences, in the projected environmental variables. Increased gross primary production (GPP) from a $\mathrm{CO}_{2}$ fertilization effect in the model compensates for the increased $R_{\mathrm{m}}$ costs associated with the warmer temperatures predicted throughout most of the loblolly pine forest-type. This $\mathrm{CO}_{2}$ compensation occurs when projected temperature increases are generally less than $35 \%$ and projected precipitation changes are greater than approximately $-10 \%$ from contemporary climate (Figs. 1, $2 \& 4$ ). However, 10 to $20 \%$ reductions in precipitation coupled with 35 to $4.5 \%$ increases in temperature predicted by the UKMO GCM for central Alabama resulted in negative NPP response or, at best, only slight increases in NPP. The coupling of the tem- perature and precipitation effects on NPP is a regional phenomenon, with inter-annual variability in climatic extremes and variation in solar radiation strongly influencing the average production response (Fig. 2). Because of the exponential relationship between temperature and $R_{\mathrm{m}}$, carbon allocation explains some of the regional response observed. Under 'typical' climatic conditions, $R_{\mathrm{m}}$ of loblolly pine may be 50 to $60 \%$ of GPP. Simulations suggest that increased temperatures drive $R_{\mathrm{m}}$ to exceedingly high proportions of GPP, with negative production predictions observed here corresponding to simulations where roughly 70 to $75 \%$ of GPP was used in $R_{\mathrm{m}}$ (Fig. 6).

The degree of $\mathrm{CO}_{2}$ compensation was GCM dependent. Increased precipitation and the strong $\mathrm{CO}_{2}$ fertilization effect in the model compensated for the 15 to $25 \%$ rise in temperatures projected by the GFDL GCM (Fig. 3a, b). An offsetting effect between photosynthesis and $R_{\mathrm{m}}$ to climate change was found for NPP projections using FOREST-BGC in Montana (Running \& Nemani 1991). Warmer temperatures also increased the length of the growing season and, therefore, annual GPP in our simulations. Higher temperature predictions for the northeastern regions in conjunction with only moderate precipitation expectations, and increased NPP projected, suggests temperature limitations to production in these areas (Figs. 3c, d \& 4c, d).

The magnitude and range in the precipitation and temperature projections and, therefore, the NPP response were directly correlated to the $\mathrm{GCM} \mathrm{CO}_{2}$

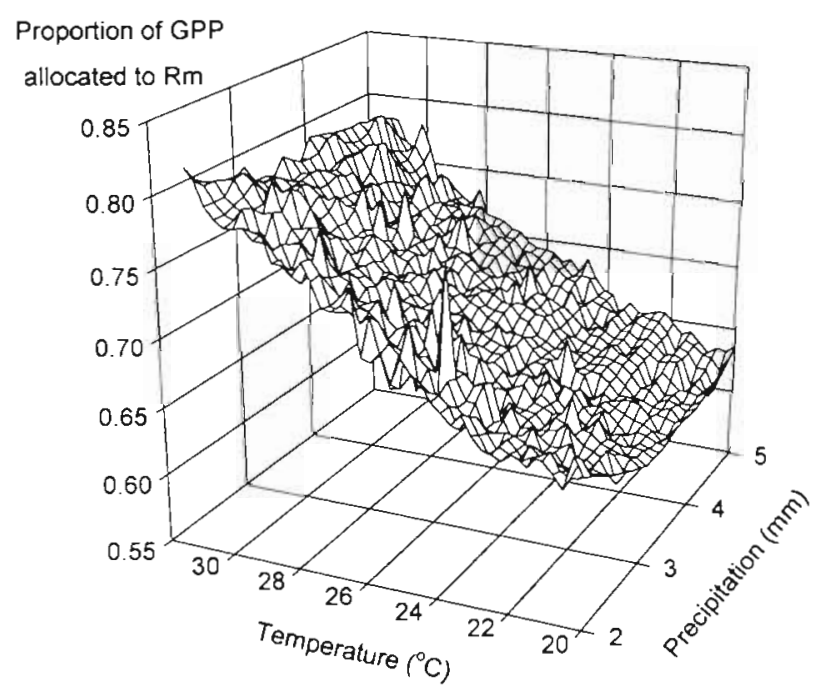

Fig. 6. The response surface illustrating the proportion of gross primary productivity used in maintenance respiration $\left(R_{\mathrm{m}}\right)$ for high $\mathrm{LAI} /$ good soil water holding capacity conditions. The surface was generated using the eighteen $1 \times 1^{\circ}$ grid cells and the 40-year projected climate from both GCMs used in this study 
sensitivity. Smith et al. (1992) found differences in above-ground carbon storage related to hierarchical differences in GCM CO 2 sensitivity. Inherent variability in GCM climate projections has been shown to be linked to incorrect or missing physics, scale of the GCM grid cells, and natural variability of climate (Ghan 1992). These results provide some evidence to suggest that there may be critical threshold levels for increases in temperature or decreases in precipitation, at least for fixed stand and site conditions. For example, temperature increases of greater than $35 \%$ combined with precipitation decreases greater than $10 \%$ of contemporary may completely offset a doubled $\mathrm{CO}_{2}$ fertilization effect in simulations assuming no $\mathrm{CO}_{2}$ acclimation in loblolly pine forests (Fig. 4c, d).

Simulations presented here represent the NPP response to an instantaneous doubling of ambient $\mathrm{CO}_{2}$ concentration with no acclimation of the photosynthetic machinery considered. $\mathrm{A} \mathrm{CO}_{2}$ fertilization effect has been repeatedly observed in $\mathrm{C} 3$ and $\mathrm{C} 4$ plant studies, however questions remain whether positive growth response will be maintained as plants acclimate to an elevated ambient $\mathrm{CO}_{2}$ environment (Acock \& Allen 1985, Conroy et al. 1990). Empirical estimates for loblolly pine indicate a 50 to $100 \%$ increase in maximum photosynthesis (AMAX) (Murthy et al. in press) and in leaf net photosynthesis (Ellsworth et al. 1995) associated with $2 \times \mathrm{CO}_{2}$ concentrations. At present, no downward trend in AMAX, or the associated elevated growth rates, has been observed under short-term chronic, elevated levels of $\mathrm{CO}_{2}$ for 11 yr old loblolly pine trees (Murthy et al. in press), or for field-grown mature 21 yr old loblolly pine trees (Liu \& Teskey 1995, Teskey 1995). A second concern in climate change modeling, examined in $\mathrm{CO}_{2}$ exposure studies, involves the effect of chronic exposure on stomatal conductance and, therefore, water use efficiency (Reynolds et al. 1992). A significant reduction in stomatal conductance for a number of C3 and C4 species has been observed (Morison 1985, Thomas \& Strain 1991). However, current evidence suggests no changes in stomatal conductance in $1.5 \times$ and $2 \times \mathrm{CO}_{2}$ treatments for $11 \mathrm{yr}$ old loblolly pine trees in branch chamber experiments (Murthy et al. in press), mature loblolly pine trees (Liu \& Teskey 1995, Teskey 1995), or in experiments using the freeair $\mathrm{CO}_{2}$ enrichment (FACE) technique (Ellsworth et al. 1995).

Nutrient limitations, and in particular nitrogen, affect the absolute photosynthetic response of plants to elevated levels of ambient $\mathrm{CO}_{2}$. Increased foliar nitrogen concentration results in increased AMAX, with nitrogen limitations to photosynthesis potentially more important than $\mathrm{CO}_{2}$ concentration (Griffin et al. 1993, Murthy et al. in press). Comins \& McMurtrie (1993) using a generic analytical ecosystem model project initial increases $(27 \%)$ in radiata pine productivity that decline to below current levels due to nitrogen limitations to photosynthesis. At present, we are unable to examine this phenomenon with our model.

Loblolly pine generally carries only 2 foliage cohorts, with current year foliage production strongly sensitive to soil nitrogen availability (NCSFNC 1991). As such, nitrogen limitations in loblolly pine forests restrict the maximum LAI attainable, provided water is not limiting (NCSFNC 1991). Droughty conditions will induce premature foliage senescence (Dougherty et al. 1995), and reduced development of the next year's foliage cohort (Hennessey et al. 1992).

Year-to-year feedbacks are not considered in this model, and would have important implications on NPP and NPP response to climate change for developing stands. For example, decreased precipitation in one year would result in lower leaf area production in the following year (Dougherty et al. 1995), resulting in reduced NPP and potentially a different response to climate projected for that year (Fig. 4c, d). Decreased nitrogen availability would decrease leaf area of the current cohort, and therefore reduce NPP, but may increase the NPP response (Fig. 4a, c).

The index of potential NPP response to an instantaneous doubling of $\mathrm{CO}_{2}$, and to the climate projections associated with this $\mathrm{CO}_{2}$ increase, provides one estimate of the climate- $\mathrm{CO}_{2}$ effect for fixed stand and site conditions for loblolly pine forests. Regional estimates of NPP on a site-specific basis using this model would require data sets not currently available. Efforts to couple data base requirements for process models at the spatial and temporal scales needed for assessments continue to be of primary importance in modeling climate change effects on forest systems (Dale \& Rauscher 1994). Because of the importance of nutrition and leaf area for loblolly pine production, a planned revision of the model to incorporate resource-driven functions for foliage phenology, production, and litterfall, as well as carbon partitioning, would enable broader application of the model. However, site-determined estimates of the resource base would still be required.

There are inherent limitations in using this model for multiple-year predictions of NPP. Although this model has previously been shown to be robust in the withinyear estimates of gross and net canopy assimilation (McMurtrie \& Wang 1993, McMurtrie et al. 1994), cumulative influences such as stand mortality and changes in site resources cannot be addressed. Future studies in this area should employ process models that incorporate short- and long-term mechanisms influencing nutrient supply and demand, and changing stand demographics. 


\section{CONCLUSIONS}

Estimates of loblolly pine NPP ranged from approxi-

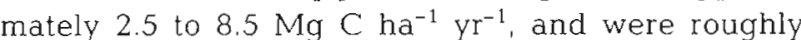
comparable to those predicted by the TEM for temperate mixed forests for a similar area of the Southeast. These estimates, however, are based on fixed stand and soil site conditions. Land-based estimates of NPP for the Southeast would require site-specific data currently unavailable for simulations using this model.

The index of potential NPP response to the climate projected for an instantaneous doubling of ambient $\mathrm{CO}_{2}$ provides one estimate of the climate- $\mathrm{CO}_{2}$ effect for fixed stand and soil site conditions for the loblolly pine forest-type. The NPP response to climate projections varied with GCM used, the LAI and water holding capacity assumed, and region examined. Variation in the $\mathrm{CO}_{2}$ sensitivity between the GFDL and the UKMO GCMs resulted in predictions of -1 to $+94 \%$ NPP under a doubling of atmospheric $\mathrm{CO}_{2}$. The magnitude and range of the NPP response to the climate projections were directly related to $\mathrm{GCM} \mathrm{CO}_{2}$ sensitivity. The GFDL model is less sensitive while the UKMO is more sensitive. Regional differences in the NPP response were coupled to the interaction between precipitation and temperature from the GCM models in conjunction with a strong $\mathrm{CO}_{2}$ fertilization effect. These NPP projections assume no acclimation to chronic, elevated $\mathrm{CO}_{2}$.

The process model sensitivity to $\mathrm{CO}_{2}$ generally offsets declines in NPP due to increased temperatures and decreased precipitation for the 2 GCMs examined. Acclimation of the photosynthetic machinery to elevated ambient $\mathrm{CO}_{2}$, including down-regulation in stomatal conductance, has not been found for loblolly pine in branch chamber experiments. If acclimation were to occur, a different productivity scenario to the climate predicted in a doubled $\mathrm{CO}_{2}$ environment would be expected. Negative production response observed in the UKMO climate scenarios was linked to the extreme increases in temperature and moderate decreases in precipitation predicted by the UKMO model.

Acknowledgements. We thank Dr Ross McMurtrie for providing the source code for BIOMASS and for his invaluable contribution in the early stages of model development. We also thank Drs Linda A. Joyce and Robert J. Mitchell for comments on the draft manuscript. Work for this project was funded, in part, by cooperative agreement No. 29-1001, USDA Forest Service and North Carolina State University.

\section{LITERATURE CITED}

Acock B, Allen LH (1985) Crop responses to elevated carbon dioxide. In: Strain BR, Cure JD (eds) Direct effects of increasing carbon dioxide on vegetation. ER-0238. United
States Department of Energy. Department of the Environment, Washington, DC, p 53-97

Anonymous (1995) Axum user's guide. TriMetrix, Inc, Seattle, WA

Benson ML, Landsberg JJ, Borough CJ (1992) The biology of forest growth experiment: an introduction. For Ecol Manage $52: 1-16$

Cannell MGR (1989) Physiological basis of wood production: a review. Scand $J$ For Res 4:459-490

Colbert SR, Jokela EJ, Neary DG (1990) Effects of annual fertilization and sustained weed control on dry matter partitioning, leaf area, and growth efficiency of juvenile loblolly slash pine. For Sci 36:995-1014

Comins HN, McMurtrie RE (1993) Long-term response of nutrient-limited forests to $\mathrm{CO}_{2}$ enrichment; equilibrium behavior of plant-soil models. Ecol Appl 3:661-681

Conroy JP, Milham M, Mazur M, Barlow EWR (1990) Growth, dry weight partitioning and wood properties of Pinus radiata D. Don after 2 years of $\mathrm{CO}_{2}$ enrichment. Plant Cell Environ 13:329-337

Cooter EJ, Eder BK, LeDuc SK, Truppi L (1993) General circulation model output for forest climate change research and applications. USDA For Serv Gen Tech Rep SE-85

Cooter EJ, Richman M, Lamb P, Sampson DA (in press) The development of a climate change data base for biological assessments in the southeastern U.S. Clim Change

Dale VH, Rauscher HM (1994) Assessing impacts of climate change on forests: the state of biological modeling. Clim Change 28:65-90

Dougherty PM, Hennessey TC, Zarnoch SJ, Stenberg PT, Holeman RT, Wittwer RF (1995) Effects of stand development and weather on monthly leaf biomass dynamics of a loblolly pine (Pinus taeda L.) stand. For Ecol Manage 72: 213-227

Ellsworth DS, Oren R, Huang C, Phillips N, Hendrey GR (1995) Leaf and canopy responses to elevated $\mathrm{CO}_{2}$ in a pine forest under free-air $\mathrm{CO}_{2}$ enrichment. Oecologia 104: $139-146$

Farquhar GD, von Caemmerer S, Berry JA (1980) A biochemical model of photosynthetic $\mathrm{CO}_{2}$ assimilation in leaves of $\mathrm{C}_{3}$ species. Planta 149:78-90

Fowells HA (1965) Loblolly pine. In: Silvics of forest trees of the United States. USDA For Serv Agric Handbook No. 271 , p $360-372$

Ghan SJ (1992) The GCM credibility gap. Clim Change 21. $345-346$

Gholz HL, Hendry LC, Cropper WP Jr (1986) Organic matter dynamics of fine roots in plantations of slash pine (Pinus elliottii) in north Florida. Can J For Res 16:529-538

Griffin KL, Thomas RB, Strain BR (1993) Effects of nitrogen supply and elevated carbon dioxide on construction cost in leaves of Pinus taeda (L.) seedlings. Oecologia 95:575-580

Hennessey TC, Dougherty PM, Cregg BM, Wittwer RF (1992) Annual variation in needle fall of a loblolly pine stand in relation to climate and stand density. For Ecol Manage 51: 329-338

Houghton JT, Jenkins GJ, Ephramus JJ (1990) Climate change the IPCC scientific assessment. Cambridge University Press, Cambridge

Karl TR, Knight RW, Easterling DR، Quayle RG (1995) Trends in U.S. climate during the twentieth century. Consequences $1: 2-12$

Kinerson RS (1975) Relationships between plant surface area and respiration in loblolly pine. J Appl Ecol 12: 965-971

Kinerson RS, Ralston W, Wells CG (1977) Carbon cycling in a loblolly pine plantation. Oecologia 29:1-10 
Liu S, Teskey RO (1995) Responses of foliar gas exchange to long-term elevated $\mathrm{CO}_{2}$ concentrations in mature loblolly pine trees. Tree Physiol 15:351-359

Malanson GP (1993) Comment on modelling ecological response to climatic change. Clim Change 23:95-109

McGuire AD, Melillo JM, Joyce LA, Kicklighter DW, Grace AL, Moore B Ill, Vorosmarty CJ (1992) Interactions between carbon and nitrogen dynamics in estimating net primary productivity for potential vegetation in North America. Global Biogeochem Cycles 6:101-124

McMurtrie RE (1985) Forest productivity in relation to carbon partitioning and nutrient cycling: a mathematical model. In: Cannell MGR, Jackson JE (eds) Attributes of trees as crop plants. Institute of Terrestrial Ecology, Abbots Ripton, UK, p 194-207

McMurtrie RE, Gholz HL, Linder S, Gower ST (1994) Climate factors controlling the productivity of pine stands: a model-based analysis. Ecol Bull 43:173-188

McMurtrie RE, Landsberg JJ (1992) Using a simulation model to evaluate the effects of water and nutrients on the growth and carbon partitioning of Pinus radiata. For Ecol Manage 52:243-260

McMurtrie RE, Leuning $R$, Thompson WA, Wheeler AM (1992) A model of the canopy photosynthesis and water use incorporating a mechanistic formulation of leaf $\mathrm{CO}_{2}$ exchange. For Ecol Manage 52:261-278

McMurtrie RE, Rook DA, Kelliher FM (1990) Modelling the yield of Pinus radiata on a site limited by water and nitrogen. For Ecol Manage 30:381-413

McMurtrie RE, Wang YP (1993) Mathematical models of the photosynthetic response of tree stands to rising $\mathrm{CO}_{2}$ concentrations and temperatures. Plant Cell Environ 16: $1-13$

McNulty SG, Vose JM, Swank WT (in press) Forest hydrology and productivity model development, testing, and validation at multi-spatial scales using a GIS. In: Quattrochi D, Goodchild J (eds) Scale in remote sensing and GIS. CRC Press, Inc, Boca Raton, FL

McNulty SG, Vose JM, Swank WT, Aber JD, Federer CA (1994) Regional-scale forest ecosystem modelling: database development, model predictions and validation using a geographic information system. Clim Res 4: $223-231$

Melillo JM, McGuire AD, Kicklighter DW, Moore B III, Vorosmarty CJ, Schloss AL (1993) Global climate change and terrestrial net primary production. Nature 363:234-240

Mignano J (1995) Effects of water and nutrient availability on root biomass, necromass, and production in a nine-yearold loblolly pine plantation. MSc thesis, Department of Forestry, North Carolina State University, Raleigh

Morison JIL (1985) Sensitivity of stomata and water use efficiency to high $\mathrm{CO}_{2}$. Plant Cell Environ 8:467-474

Murthy R, Dougherty PM, Zarnoch SJ, Allen HL (in press) Effects of elevated $\mathrm{CO}_{2}$, nitrogen, and water on net photosynthesis and foliar nitrogen concentration of loblolly pine trees. Tree Physiol

NCSFNC (North Carolina State Forest Nutrition Cooperative) (1991) Leaf area variation in midrotation loblolly pine

Editor: V. Meentemeyer, Athens, Georgia, USA plantations. NCSFNC Res Note No. 6. College of Forest Resources, North Carolina State University, Raleigh

NCSFNC (North Carolina State Forest Nutrition Cooperative) (1993) Six-year growth responses of midrotation loblolly pine plantations to $\mathrm{N}$ and $\mathrm{P}$ fertilization. NCSFNC Rep No. 31. College of Forest Resources, North Carolina State University, Raleigh

Pastor J, Post WM (1988) Response of northern forests to $\mathrm{CO}_{2}$ induced climate change. Nature 334:55-58

Raich JW, Rastetter EB, Melillo JM, Kicklighter DW, Steudler PA, Peterson BJ (1991) Potential net primary productivity in South America: application of a global model. Ecol Appl $1: 399-429$

Reynolds JF, Hilbert DW, Chen J, Harely PC, Kemp PR, Leadley PW (1992) Modelling the response of plants and ecosystems to elevated $\mathrm{CO}_{2}$ and climate change. TR-054 . United States Department of Energy, Department of the Environment, Washington, DC

Richman MB, Lamb PJ (1985) Climatic pattern analysis of three- and seven day summer rainfall in the central United States: some methodological considerations and a regionalization. J Clim Appl Meteorol 24:1325-1343

Richman MB, Lamb PJ (1987) Pattern analysis of growing season precipitation in Southern Canada. AtmosphereOcean 25:135-158

Rosenzweig C, Parry ML, Fischer G. Frohberg K (1993) Climate change and world food supply. Res Rep No. 3, Environmental Change Unit, University of Oxford

Running SW, Nemani RR (1991) Regional hydrologic and carbon balance responses of forests resulting from potential climate change. Clim Change 19:349-368

Saxton KE, Rawls WJ, Romberger JS, Papendick RI (1986) Estimating generalized soil-water characteristics from texture. Soil Sci Soc Am J 50:1031-1036

Smith JB, Tirpak DA (eds) (1990) The potential effects of global climate change on the United States. Hemisphere Publ Corp, New York

Smith TM, Leemans R, Shugart HH (1992) Sensitivity of terrestrial carbon storage to $\mathrm{CO}_{2}$-induced climate change: comparison of four scenarios based on general circulation models. Clim Change 21:367-384

Teskey RO (1995) A field study of the effects of elevated $\mathrm{CO}_{2}$ on carbon assimilation, stomatal conductance and leaf and branch growth of Pinus taeda trees. Plant Cell Environ 18 $565-573$

Teskey RO, Bongarten BC, Cregg BM, Dougherty PM, Hennessey TC (1987) Physiology and genetics of tree growth response to moisture and temperature stress: an examination of the characteristics of loblolly pine (Pinus taeda L.). Tree Physiol 3:41-61

Thomas RB, Strain BR (1991) Root restriction as a factor in photosynthetic acclimation of cotton seedlings grown in elevated carbon dioxide. Plant Physiol 96:627-634

Vose J, Allen HL (1988) Leaf area, stemwood growth, and nutrition relationships in loblolly pine. For Sci 34:547-563

Vose J, Allen HL (1991) Quantity and timing of needlefall in N and $\mathrm{P}$ fertilized loblolly pine stands. For Ecol Manage 41: $205-219$

Manuscript furst received: December 27, 1995

Revised version accepted: May 6, 1996 